http://dx.doi.org/10.12775/szhf.2021.018

\author{
WALTER E. BLOCK \\ Loyola University New Orleans, USA \\ E-MAIL:WBLOCK@LOYNO.EDU \\ ORCID: 0000-0003-2215-4791
}

\title{
Murray Rothbard, Anarchist
}

\begin{abstract}
This essay is in honor of Murray N. Rothbard. He made many important, nay, exquisite contributions to belles letters, not limited to economics, history, philosophy, sociology; even to movie reviews of all things. The present essay is an attempt to honor him by making the case for free market anarchism, the thesis that ran through most of his intellect output.
\end{abstract}

Keywords: anarchism, government, anarcho-capitalism, libertarianism

\section{Introduction}

When the non-cognoscenti think of this political philosophy, their minds immediately focus on bomb-throwing and chaos.

As to the former, it is statism, not anarchism, that is responsible for mass murder. The best estimates are that governments, not anarchists, are responsible for some 200 million unjustified deaths, e.g., murders, in the last century, 
and this ignores those killed in the numerous wars these organizations are continually fighting with one another. ${ }^{1}$

As to the latter, there is that famous calumny-joke "anarchists unite." But it is no logical contradiction for the anti-statists to do precisely that. Etymologically, the prefix "an" in anarchy simply means "against." So, what is it that anarchists oppose? Why "archy" of course. And what is that meaning of that suffix? It is: unjustified rule. So anarchists are not against rules, per se, only unjustified ones. This, in turn, leads to the question of which rules are justified, which ones not? From the libertarian point of view which animates Rothbard's thought, ${ }^{2}$ there are two foundational building blocks of this philosophy which answer that question. The first is the non-aggression principle (NAP): it is illicit for anyone to initiate, or threaten, violence against all innocent people and their possessions. And what, in turn, determines legitimacy?

1 See on this: Walter E. Block, "Deaths by Government: Another Missing Chapter". LewRockwell.com, 27.11.2006. Access 9.11.2021, https://www.lewrockwell.com/2006/11/ walter-e-block/deaths-by-government-anothermissingchapter/; Fred Branfman, "World's Most Evil and Lawless Institution? The Executive Branch of the U.S. Government". Alternet, 26.6.2013, access 9.11.2021, http://www.alternet.org/investigations/executive-branch-eviland-lawless?paging=off; Robert Conquest, The Harvest of Sorrow (New York: Oxford University Press, 1986); Robert Conquest, The Great Terror. Edmonton (Alberta: Edmonton University Press, 1990); Stephane Courtois et al., The Black Book of Communism: Crimes, Terror, Repression, transl. Jonathan Murphy, Mark Kramer (Cambridge, MA: Harvard University Press, 1999); Thomas DiLorenzo, "Death by Government: The Missing Chapter", LewRockwell.com, 22.11.2006, access 9.11.2021, http://www.lewrockwell.com/dilorenzo/dilorenzo114. html; Richard M. Ebeling, "The human cost of socialism in power", The Future of Freedom Foundations, 9.9.2015, access 9.11.2021, https://www.fff.org/explore-freedom/article/the-human-cost-of-socialism-in-power/; R. J. Rummel, Democide: Nazi Genocide and Mass Murder (Rutgers, New Jersey: Transaction Publisher, 1992); R. J. Rummel, Death By Government (New Brunswick, NJ: Transaction, 1994); R. J. Rummel, Statistics on Democide (Charlottesville, VA: Center on National Security and Law, University of Virginia, 1997). This also ignores hundreds of thousands of annual highway fatalities on public roads, which are also the responsibility of government; Walter E. Block, The Privatization of Roads and Highways: Human and Economic Factors (Auburn, AL: The Mises Institute, 2009).

2 See Murray N. Rothbard, For a New Liberty (New York: Macmillan, 1973) and Murray N. Rothbard, "Law, Property Rights, and Air Pollution", Cato Journal 2 (1982), 1. Reprinted in Walter E. Block, ed., Economics and the Environment: A Reconciliation (Vancouver: The Fraser Institute 1990). 
Private property rights based on initial homesteading ${ }^{3}$ of virgin land, and any and all subsequent voluntary alterations, e.g., legitimate title transfers, such as sale, gift, gambling.

In section II of this paper we discuss several considerations in defense of laissez faire anarchism. They are as follows: 1 . Taxation; 2 . World government; 3. Secession; 4. Economic efficiency; 5. Initiation of this institution; 6. Why there are so few capitalist anarchists?; 7. A statist contradiction; 8. How anarchy would work; 9. The Somalia objection; 10. Why do most economists reject anarcho-capitalism? 11. Nozick's critique. We conclude in section II.

\section{Taxation}

Exhibit "A" in the case against statism is taxation. No truer words were ever uttered than that "taxation is theft." But is not taxation voluntary, at least in civilized countries such as the United States and in the first world, which includes Europe and Japan? No, it is not. Those who think it is are invited to decline to make these payments, and observe what happens to them. Oh, it cannot be denied that the first reaction of the all-loving state will not be violence. Instead, a relatively polite letter will first be received by the nonpayer, mentioning that the tax system is voluntary, and depends upon the good will of the taxpayers. A follow up missive might even mention all the good things the bureaucrats will do with the funds they receive. But, eventually, a man in a blue uniform, a gun and a badge will show up at the door of the "tax cheat," and politely ask him to accompany him to jail, after a government court has decided that, yes, these funds are owed. If this "invitation" is accepted, kidnapping, a prison sentence, will ensue. If not, an even more harsh reaction will occur.

But do we not owe government tax money based on the expenditures they make in our behalves? No; even assuming their spending benefits us, that does not justify coercive payments to them. If we join a golf or tennis club, we will have to pay dues. Are not taxes the equivalent of club dues? No, they are

3 See John Locke, An Essay Concerning the True Origin, Extent and End of Civil Government, in: John Locke, Two Treatises of Government, ed. P. Laslett (Cambridge: Cambridge University Press 1960), 17-18. 
not. In the latter case we signed a contract obligating ourselves to make such payments; but there is simply no signed contract with the state. ${ }^{4}$

What about the objection that by living in a country, we have implicitly "contracted" to pay it "dues?" This is sometimes articulated in the form of: "If you don't like it here, don't want to pay taxes, then leave." But that objection is problematic in that there were people living in the territory claimed by the government before its inception. For example, the U.S. began in 1776, but there were many individuals who homesteaded land before that, and were thus the proper owners of it. Why should they or their heirs be forced to depart? Yes, a majority of the people living there at that time might have supported this establishment, but why should people who did not agree to be bound by such a vote be compelled to obey its strictures?

This ploy is also circular. It assumes the truth of the very point at issue. The contention of the statists is that the government in effect owns the right to control all the people in its domain, and all their property. The anarchists deny this claim. The "leave" ploy assumes, with no evidence, no argument, no nothing, that the government's argument is correct.

No, taxation is a blatant violation of the NAP, and if these were the only flaw in the case for statism, that would be sufficient to deduce anarchism, at least for the fully consistent libertarian. But there is more, much more.

\section{World government}

Here is a reductio ad absurdum in the case for the state. The argument goes as follows. Jones and Smith get into an argument with each other about who owns a particular property. They cannot settle it between themselves. Therefore, a government is needed to reach a proper determination of the rights of the case. But, if this is true, Argentina and Albania, or Brazil and Burundi, or Canada and Cameroon ${ }^{5}$ might also find themselves in a serious altercation.

4 According to Schumpeter: "The theory which construes taxes on the analogy of club dues or of the purchase of the services of, say, a doctor only proves how far removed this part of the social science is from scientific habits of mind." Joseph A. Schumpeter, Capitalism, Socialism and Democracy (New York: Harper, 1942), 198.

5 Notice the lovely alliteration? We can continue: Denmark and Djibouti, Egypt and Ecuador, France and Finland, Greece and Ghana, Haiti and Hungary. 
What is true for Smith and Jones applies, also, to any other set of potential combatants. If a national government is required to deal properly with any two individuals, why, then, nothing less than a world government will suffice for any two nations. It cannot be denied that here is a logical equivalence: the local government is to its inhabitants as would be the world government to all the nations on the planet.

But there are numerous and serious problems with such an entity. One point is utilitarian. China and India, between them, would compromise, almost, a majority of the votes of the entire world, were this institution run on a democratic basis. ${ }^{6}$ Another is the plight of the Jews and other out of favor groups. The history of this people consists of running from one country to another, always seeking a modicum of safety. With almost 200 different nations, before the establishment of Israel, if one jurisdiction prohibited their entry, perhaps another would welcome them. With world government, there would be no other place for such a minority to escape to, when out of favor. The point is, with this institution, we would be putting all of our eggs in one basket; if its leaders turned dictatorial, there would be no other option.

There is nothing wrong with democracy per se, as long as the voters agree to be bound by the vote in advance. For example, the chess club holds an election concerning the date of the regular meetings: Tuesday or Wednesday. No one who takes part in this election is forced to comply. Or, the shareholders hold a ballot on some commercial undertaking. Those dissatisfied with the result can sell their shares. In any case, assuming no fraud, they went into this investment with their eyes open: they knew beforehand that choices were made in this manner. In sharp contrast, under political democracy, people are forced to join and abide by the viewpoint of the majority. This is a very different kettle of fish.

${ }^{6}$ For a powerful rejection of political democracy, see Hans-Hermann Hoppe, Democracy - The God That Failed: The Economics and Politics of Monarchy, Democracy, and Natural Order (Rutgers University, N.J.: Transaction Publishers, 2001). 


\section{Secession}

We have already mentioned the NAP and private property rights as the foundational principles of libertarianism. A third one might well be free association (FA). No one should be forced to associate with anyone else against his will. The problem with slavery and rape, the only difficulty with these two horrendous and despicable acts, is that they violate FA. With FA, slavery turns into a voluntary sado-masochistic relationship. With FA, rape becomes voluntary sexual intercourse. The point is, if you are compelled to associate with someone, against your will, you are the victim of a crime.

Therefore, if you find yourself in an association you wish to sever, unless you are contractually obligated via your own previous volition to do so, you may end the relationship, or not begin one such in the first place. Thus, if Louisiana wishes to secede from the union, they may do so. If New Orleans desires to separate itself from the Pelican State, they also have that right. And, if the Garden District no longer wishes to be part of the Crescent City, the same consideration applies. Where does this process end? It concludes at the individual level. For if Joe Blow an inhabitant of this neighborhood no longer wishes to march in tandem with those living nearby him, to compel him to do so is to commit a crime against him.

But secession down to the individual person is equivalent to anarchism. Another way to put this is to say that, paradoxically, the anarchist goal is a sovereign nation for each and every one of us. The ideal, here, is some seven and a half billion different countries, none of them beholden to any other such entity. In that way, and only in that way, would the right of FA be upheld.

To deny this, then, to insist that, yes, upon occasion secession of a state or a city from a country is justified, but no further, certainly this should not apply to individual persons, is to engage in an egregious rights violation. ${ }^{7}$

7 There are implications of FA for more than anarchism. For example, all non-discrimination laws would be deemed invalid under libertarianism, whether on the basis of race, or sex, or religion, or any other criterion. For, these laws coerce some people to deal with others who they would prefer to avoid. It would take us too far afield from our present purposes to defend this claim, however. For the case against all such discrimination legislation, including so-called "affirmative action," see Walter E. Block, "Economic Intervention, Discrimination and Unforeseen Consequences", in: Discrimination, Affirmative Action and Equal Opportunity, 
ed. Walter E. Block, Michael A. Walker (Vancouver: The Fraser Institute, 1982), 101-125; Walter E. Block, "Directions for Future Research in Equal Pay Legislation", in: Towards Equity: Proceedings of a Colloquium on the Economic Status of Women in the Labour Market, ed. Muriel Armstrong (Ottawa: The Economic Council, 1985), 119-21, 134-135, 179-182; Walter E. Block, "Discrimination: An Interdisciplinary Analysis", The Journal of Business Ethics 11: 241-254; Walter E. Block, "Compromising the Uncompromisable: Discrimination", American Journal of Economics and Sociology 57 (1998), 2: 223-237; Walter E. Block, Michael A. Walker, Focus on Employment Equity: A Critique of the Abella Royal Commission on Equality in Employment (Vancouver: The Fraser Institute, 1985); Walter E. Block, Walter E. Williams, "MaleFemale Earnings Differentials: A Critical Reappraisal”, The Journal of Labor Research II (1981), 2: 385-388; Walter E. Block, Nicholas Snow, Edward Stringham, "Banks, Insurance Companies and Discrimination", Business and Society Review 113 (2008), 3: 403-419; Linda S. Gottfredson, "Societal consequences of the g factor in employment", Journal of Vocational Behavior 29 (1986): 379-410; Richard J. Herrnstein, Charles Murray, The Bell Curve: Intelligence and Class Structure in American Life (New York: The Free Press, 1994); Arthur R. Jensen, Straight Talk about Mental Tests (New York: Free Press, 1981); Michael Levin, Feminism and Freedom (New York: Transaction Books, 1987); Michael Levin, Why Race Matters: Race Differences and What They Mean (New York: Praeger Publishers, 1997); Richard Lynn, Tatu Vanhanen, IQ And The Wealth Of Nations (New York, N.Y.: Praeger Publishers, 2002); Richard Lynn, Tatu Vanhanen, IQ and Global Inequality (Washington: Summit Publishers, 2006); Heather MacDonald, The Diversity Delusion: How Race and Gender Pandering Corrupt the University and Undermine Our Culture (New York: St. Martin's Press, 2018); Ryan McMaken, “The Trouble with „Public Accommodation”, Mises Institute, 3.6.2016, access 9.11.2021, https://mises.org/ wire/trouble-public-accommodation; Ilana Mercer, "The Silly Sex", V-Dare.com, 6.1.2005, access 9.11.2021, http://www.vdare.com/misc/mercer_050106_silly.htm; Charles Murray, "Jewish Genius", Commentary, April 2007, access 9.11.2021, https://www.commentary.org/ articles/charles-murray/jewish-genius/; Murray N. Rothbard, „Law, Property Rights, and Air Pollution”, Cato Journal 2 (1982), 1; Philippe J. Rushton, “The reality of racial differences: A rejoinder with new evidence", Personality and Individual Differences 9 (1988): 1035-1040; Philippe J. Rushton, "Reply to Wilerman on Mongoloid-Caucasoid Differences in Brain Size", Intelligence 15 (1991): 365-367; Philippe J. Rushton, "Brain size and cognitive ability: Correlations with age, sex, social class and race", Psychonomic Bulletin and Review 3 (1996), 1:21-36; Philippe J. Rushton, R.T. Osborne, "Genetic and environmental contributions to cranial capacity estimated in Black and White adolescents", Intelligence 20 (1995): 1-13; Philippe J. Rushton, C. D. Ankney, "The evolutionary selection of human races: A response to Miller", Personality and Individual Differences 15 (1993): 677-680; Daniel Seligman, A Question of Intelligence, The IQ Debate in America (New York: Citadel, Carol Press, 1992); Thomas Sowell, Race and Economics (New York: Longman, 1975); Thomas Sowell, Markets and Minorities (New York, N.Y.: Basic Books, 1981); Thomas Sowell, "Weber and Bakke and the presuppositions of 'Affirmative Action"', in: Discrimination, Affirmative Action and Equal Opportunity, eds. Walter E. Block, Michael Walker (Vancouver: The Fraser Institute, 1982), 37-63; Thomas Sowell, The Economics and Politics of Race: An International Perspective (New York, William Morrow, 1983); Thomas Sowell, Civil Rights: Rhetoric or Reality (New York: William Morrow, 


\section{Economic efficiency}

It is an axiom of economics that competition brings about a better product, more of it, and, at a cheaper price. It would be the rare person who would deny such a basic premise of economics 101. I do not say the more competitors the better, necessarily, because there are economies of scale. But, no one should be prevented from entering the fray. Restrictions on entry are uneconomic, apart from violating rights.

But this applies, as well, to the services we usually associate with government: courts supply justice, police and armies protect us from marauders, we need roads and highways, water and sewer services, etc. However, governments insist upon a monopoly in the provision of these benefits. Government sees itself as the only provider of these services within a given geographical area. Indeed, that is virtually the only definition of this institution. ${ }^{8}$ Thus, this consideration too leads us in the direction of anarchy, where there are no restrictions on entry.

1984); Thomas Sowell, Basic Economics: A Citizen's Guide to the Economy (New York, N.Y.: Basic Books, 2000); Laurence Vance, "The Right to Discriminate Is a Basic Property Right", Mises Institute, 24.3.2017, access 9.11.2021, https://mises.org/blog/right-discriminate-basicproperty-right; Deborah Walker et al., "The Feminist Competition/Cooperation Dichotomy: A Critique", Journal of Business Ethics 55 (2004), 3: 241-252; Roy Whitehead, Walter E. Block, Lu Hardin, "Gender Equity in Athletics: Should We Adopt a Non-Discriminatory Model?", The University of Toledo Law Review 30 (1999), 2: 223-249; Roy Whitehead, Walter E. Block, "Sexual Harassment in the Workplace: A Property Rights Perspective", University of Utah Journal of Law and Family Studies 4 (2002): 226-263;Roy Whitehead, Walter E. Block, "The Boy Scouts, Freedom of Association and the Right to Discriminate: A Legal, Philosophical and Economic Analysis", Oklahoma City Law Review 29 (2004), 3: 851-882; Walter E. Williams, The State Against Blacks (New York: McGraw-Hill, 1982); Walter E. Williams, Race and Economics: How Much Can Be Blamed on Discrimination? (Stanford, CA: Hoover Institution Press, 2011); Paul Wood, "First They Came for the Bakers", LewRockwell.com, 22.5.2015, access 9.11.2021, https://www.lewrockwell.com/2015/05/no_author/first-they-came-for-thebakers/; Thomas E. Woods, "Fashionable Libertarians Declare: HERE We Need Aggression!", LewRockwell.com, 7.6.2016, access 9.11.2021, https://www.lewrockwell.com/2016/06/thomaswoods/forget-called-religious-liberty-laws.

8 Governments can "contract out" some of these services, but it retains overall monopoly control with regard to them. 


\section{Initiation of this institution}

Let us start de novo. We are now in a situation in which there is no government. We are all anarchists now. But someone gets up on his hind legs and says to his fellows: "Hey, let's start up a government. We can pool some of our resources, democratically elect a president, prime minister, a parliament, a congress, whatever. They will do what governments usually do." Would this start-up be compatible with libertarian law?

Not at all. First, let us consider the most likely positive scenario: a majority of the people in the area agree; posit that $85 \%$ support this initiative, $10 \%$ vote against, and 5\% decline to register their views, one way or the other. There are no secret ballots. Everything is above-board ${ }^{9}$. What to do with the recalcitrant $15 \%$ ? It would be intellectually difficult to tell them to leave if they do not support this new state, since that would constitute a clear rights violation if ever there was one

It is extremely unlikely there would be unanimous consent. But, just suppose that is the result. Do we now support the government philosophy? Not at all. For, if everyone, without exception, gave his imprimatur to this new entity, it would not be a government at all; rather, it would be a contractual arrangement on the part of numerous people. That is, the very essence of government is coercion. If there is no intimidation, none at all, then, the institution in question is part of the market, not an aspect of the state apparatus.

The government has no right to do to a person what no individual may do to any other individual. By simply declaring themselves a state, the individuals connected to it do not suddenly gain rights they did not have before this declaration. If it is claimed that they do, from whence do these additional rights spring? Out of the very thin air is the only proper response. Namely, there is no justification for this at all. Might simply does not make right. And, this is all that the government can call upon: might. There is indeed such a thing as the tyranny of majority. This is yet another unjustified crutch the government can call upon to buttress its claim, but this is as invalid as any other defense available to it.

9 See Lysander Spooner, No Treason: The Constitution of No Authority and A Letter to Thomas F. Bayard (Larkspur, Colorado: Rampart College, 1966 [1870]). 
Hoppe brilliantly demonstrates why it would be difficult, nay, impossible, to get such an institution off the ground, by voluntary means:

Let me begin with the definition of a state. What must an agent be able to do to qualify as a state? This agent must be able to insist that all conflicts among the inhabitants of a given territory be brought to him for ultimate decision-making or be subject to his final review. In particular, this agent must be able to insist that all conflicts involving himself be adjudicated by him or his agent. And implied in the power to exclude all others from acting as ultimate judge, as the second defining characteristic of a state, is the agent's power to tax: to unilaterally determine the price that justice seekers must pay for his services. Based on this definition of a state, it is easy to understand why a desire to control a state might exist. For whoever is a monopolist of final arbitration within a given territory can make laws. And he who can legislate can also tax. Surely, this is an enviable position. More difficult to understand is how anyone can get away with controlling a state. Why would others put up with such an institution? ${ }^{10}$

10 Hans-Hermann Hoppe, "State or Private Law Society”, LewRockwell.com, 10.4.2011, access 9.11.2021, http://www.lewrockwell.com/hoppe/hoppe26.1.html. For the libertarian anarchist opposition to government, see Terry L. Anderson, P.J. Hill, "An American Experiment in Anarcho-Capitalism: The Not So Wild, Wild West", Journal of Libertarian Studies 3 (1979): 9-29; Bruce L. Benson, "Enforcement of Private Property Rights in Primitive Societies: Law Without Government", The Journal of Libertarian Studies IX (1989), 1: 1-26. Bruce L. Benson, "Customary Law with Private Means of Resolving Disputes and Dispensing Justice: A Description of a Modern System of Law and Order without State Coercion", The Journal of Libertarian Studies IX (1990), 2: 25-42; Walter E. Block, "Anarchism and Minarchism; No Rapprochement Possible", Journal of Libertarian Studies 21 (2007), 1: 91-99; Walter E. Block, "Governmental inevitability: reply to Holcombe”, Journal of Libertarian Studies 22 (2011): 667-688.; Walter E. Block, Michael Fleischer, "How Would An Anarchist Society Handle Child Abuse?", LewRockwell.com, 13.10.2010, access 9.11.2021, http://www.lewrockwell.com/block/block167.html; Doug Casey, “Doug Casey on Anarchy”, Casey Research, 31.3.2010, access 1.4.2010, http://www. caseyresearch.com/cwc/doug-casey-anarchy; Gerard Casey, Libertarian Anarchy: Against the State (Bloomsbury Academic, 2012); Thomas J. DiLorenzo, "The Culture of Violence in the American West: Myth versus Reality”, The Independent Review 15 (2010), 2: 227-239; Randy England, “The state: what can we replace it with?”, LewRockwell.com, 31.3.2013, access 9.11.2021, http://www.lewrockwell.com/blog/lewrw/archives/134782.html; Anthony Gregory, "Abolish the Police", LewRockwell.com, 26.5.2011, access 9.11.2021, http://www.lewrockwell.com/ gregory/gregory213.html; Gil Guillory, Patrick Tinsley, "The Role of Subscription-Based Patrol and Restitution in the Future of Liberty", Libertarian Papers 1 (2009), 12: 1-40; John Hasnas, "The myth of the rule of law", Wisconsin Law Review 199 (1995); David J. Heinrich, "Justice for All Without the State", The Libertarian Standard, 6.5.2010, access 9.11.2021, http://www.libertarianstandard.com/articles/david-j-heinrich/justice-for-all-without-the-state/; Robert Higgs, 
"Why We Couldn't Abolish Slavery Then and Can't Abolish Government Now", LewRockwell. com, 20.8.2009, access 9.11.2021, http://www.lewrockwell.com/higgs/higgs128.html; Robert Higgs, "What is the point of my libertarian anarchism?", LewRockwell.com, 16.1.2012, access 9.11.2021, http://archive.lewrockwell.com/higgs/higgs180.html; Robert Higgs, "The State Crown Jewel of Human Social Organization", LewRockwell.com, 13.7.2013, access 14.7.2013, http://www.lewrockwell.com/blog/lewrw/archives/135000. html;Hans-Hermann Hoppe, "Reflections on the Origin and the Stability of the State", LewRockwell.com, 23.6.2008, access 9.11.2021, http://www.lewrockwell.com/hoppe/hoppe18.html; Hans-Hermann Hoppe, "State or Private Law Society", LewRockwell.com, 10.4.2011, access 9.11.2021, http://www.lewrockwell. com/hoppe/hoppe26.1.html; Jacob Huebert, Libertarianism Today (Santa Barbara, CA: Praeger, 2010); Seth King, "Daily Anarchist Interviews Walter E. Block", LewRockwell.com, 9.9.2010, access 9.11.2021, http://www.lewrockwell.com/block/block165.html; Stephan Kinsella, "The Irrelevance of the Impossibility of Anarcho-Libertarianism", StephanKinsella.com, 20.8.2009, access 9.11.2021, http://www.stephankinsella.com/2009/08/20/the-irrelevance-of-the-impossibility-of-anarcho-libertarianism/; Roderick Long, "Libertarian Anarchism: Responses to Ten Objections", LewRockwell.com, 19.8.2004, access 9.11.2021, http://www.lewrockwell. com/long/long11.html; Michael McConkey, "Anarchy, Sovereignty, and the State of Exception: Schmitt's Challenge", The Independent Review 17 (2013), 3: 415-428; Stefan Molyneux, "The Stateless Society: An Examination of Alternatives", The Mail Archive, 1.2.2008, access 9.11.2021, http://www.mail-archive.com/libertarianenterprise@yahoogroups.com/msg02056. html; Stefan Molyneux versus Michael Badnarik, "How much government is necessary", Freedomain, 5.7.2009, access 9.11.2021, http://www.freedomainradio.com/Videos.aspx; Robert P. Murphy, “But Wouldn’t Warlords Take Over?”, Mises Institute, 7.7.2005, access 8.7.2005, http://mises.org/story/1855; http://mises.org/library/wouldnt-warlords-take-over; Robert P. Murphy, "Overrating Government Service", Mises Institute, 15.3.2010, access 9.111.2021, http://mises.org/daily/4131?utm_source=Ludwig+von+Mises+Institute+of+Canada+Daily+ List\&utm_campaign=e4794b19d8-RSS_EMAIL_CAMPAIGN\&utm_medium=email\&utm_ term=0_6c2fea3584-e4794b19d8-274221537; Robert P. Murphy, "Where Are the Rothbardian Defense Agencies?”, Mises Institute, 14.12.2013, access 15.12.2013, https://www.mises.ca/ where-are-the-rothbardian-defense-agencies; Robert P. Murphy, "Drug Gangs and Private Law", Mises Institute, 17.12.2013, access 9.11.2021, http://mises.ca/posts/blog/drug-gangs-andprivate-law/; Robert P. Murphy, "Randians versus Rothbardians", Mises Institute, 22.12.2014, access 9.11.2021, http://mises.ca/posts/blog/randians-versus-rothbardians/; Paul Ron, You Tube, Undated. http://www.youtube.com/watch?v=7o4kiWpqoeg\&feature=PlayList\&p=9645F6A6 8683F679\&playnext=1\&playnext_from=PL\&index=4; Llewellyn Jr. Rockwell H., Against the State: An Anarcho-Capitalist Manifesto (Auburn, AL: Rockwell Communications LLC, 2014); Llewellyn Jr. Rockwell H., "What Libertarianism Is, and Isn't", LewRockwell.com, 31.3.2014, access 9.11.2021, http://www.lewrockwell.com/2014/03/lew-rockwell/what-libertarianism-isand-isnt/; Murray N. Rothbard, For a New Liberty (New York: Macmillan, 1973); Murray N. Rothbard. "Society Without a State", The Libertarian Forum 7 (1975), 1; Murray N. Rothbard, "Do you hate the state?", The Libertarian Forum 10 (1977), 7; Murray N. Rothbard, The Ethics of Liberty (New York: New York University Press, 1998); Butler Shaffer, The Wizards of Ozymandias: Reflections on the Decline and Fall (Auburn, AL: The Mises Institute, 2012), 224-235; 
An argument against private courts ${ }^{11}$ is that people cannot be trusted to be judges in their own case. But, surely, this applies, also, to the statist apparatus. When a plaintiff sues the government, he does so, perforce, in a government court.

\section{Why there are so few capitalist anarchists?}

Let us start our answer to this question by asking a broader one; why are there so few libertarians? And, before we get to that issue, we must note that most supporters of this latter philosophy are not anarchists. The overwhelming majority are limited government or minimal government libertarians, that is, minarchists. Ayn Rand, for example, favors a very small state, one limited to armies, courts and police. Why are there so few such people? Why did Ron Paul, perhaps the most high profile libertarian now active, fare so poorly in electoral politics?

My answer is that this is a result of biology. We are hard-wired not to favor laissez faire and free enterprise. ${ }^{12}$ Instead, we are, most of us, inclined toward explicit benevolence, rather than the implicit variety thereof created by free markets.

How, then, have most libertarians arrived at this perspective, if they are disposed through biology in the opposite direction. They are biological mutants. No, most were not born that way; but they had the hard wiring to at least be open to the case for economic freedom. And, since anarcho-capitalists are

Peter Sloterdijk, “The Grasping Hand: The modern democratic state pillages its productive citizens", CITY JOURNAL, The Manhattan Institute, Winter 2010, http://www.city-journal. org/2010/20_1_snd-democratic-state.html; Lysander Spooner, No Treason: The Constitution of No Authority and A Letter to Thomas F. Bayard (Larkspur, Colorado: Rampart College, 1966 [1870]); Edward Stringham, ed., Anarchy and the Law: The Political Economy of Choice (Somerset, NJ: Transaction Publishers, 2007); Morris Tannehill, Linda Tannehill, The Market for Liberty (New York: Laissez Faire Books, [1970] 1984); Patrick Tinsley, "With Liberty and Justice for All: A Case for Private Police”, Journal of Libertarian Studies 14 (1998-1999), 1: 95-100; Robert Wenzel, "Robert Ringer's Strawman Anarchist", LewRockwell.com, 2.2.2013, access 9.11.2021, http://archive.lewrockwell.com/wenzel/wenzel211.html.

11 See below.

12 See John Levendis, Walter E. Block, Robert B. Eckhardt, "Evolutionary psychology, economic freedom, trade and benevolence", Review of Economic Perspectives - Národohospodářský obzor 19 (2019), 2: 73-92. 
but a small proportion of the tiny group who are libertarians, they are, to coin a phrase, "mutants squared."

But this is not true of all those who characterize themselves as "anarchists." There is also the left-wing variety thereof. Chomsky ${ }^{13}$ is perhaps the most famous representative of this position. I do not at all see him as a mutant, at least not in this regard. His economics ranges from illiterate to indifferent. He opposes profit, markets, money, private property, price gouging, etc. In this way, his views are indistinguishable from other left wing critics of economic freedom.

For most people, the "unwoke" government is inevitable. No statist seriously protests death and taxes, because they thought not be able to be avoided. This, at least, is the mind-set of those who are hard-wired in this direction, and unable to throw off anarchistic thinking, no matter how cogent it is.

\section{A statist contradiction}

But do we not need a government to protect rights? Certainly not, for, the only way this entity can protect rights is by first violating them. We see a government policeman stopping a theft. We applaud. We think, well, maybe, the state is not as bad as we anarchists had thought. But, the only reason the cop is on the beat in the first place is that he has been paid a salary. And from whence sprung the wherewithal to cover these costs? Why, from strong-arm tactics which necessarily accompany taxation, or at least by such a threat, which ensures compliance without any explicit violence.

13 Noam Chomsky, Language and Responsibility (New York: Pantheon Books, 1977); Noam Chomsky, Radical Priorities (Montreal: Black Rose Books, 1981); Noam Chomsky, On Power and Ideology (Boston: South End Press, 1987); Noam Chomsky, "Simple truths, hard problems: Some thoughts on terror, justice, and self-defence”, Philosophy 80 (2005): 5-28; Noam Chomsky, "Humanitarian imperialism: The new doctrine of imperial right", Monthly Review 60 (2008): 22-50; Noam Chomsky, "Noam Chomsky on US Libertarian Party", You Tube, 24.11.2011, access 9.11.2021, http://www.youtube.com/watch?v=gbL3zRgZUBo; for a libertarian take on this author, James Ostrowsky, "Chomsky's Economics", Mises Institute, 6.1.2003, access 9.11.2021, https://mises.org/library/chomskys-economics; Richard Wall, "Who's Afraid of Noam Chomsky?", LewRockwell.com, 17.8.2004, access 9.11.2021, https:// www.lewrockwell.com/2004/08/richard-wall/whos-afraid-of-noam-chomsky. 
The point is, it is impossible to protect rights by first violating them. Yes, if we look at the gendarme's good works, and it is impossible to deny that there are those, the state shows a benign face. But when we view this in full context, it is difficult to make such an assessment.

\section{How anarchy would work}

Let us consider how private courts-defense agencies would function. Assume the following five people: Al, Bob, Clarence, Dave and Ed. The first and fifth of these enter into a dispute. One of them claims he purchased 100 cows from the other, duly paid for them in advance, and received only 90 of these farm animals, and 25 of them were sick. The other just as vociferously denies this claim. Under statism, the next step would be obvious: the one sues the other in a government court.

How would this situation be resolved in the absence of the state? It might occur as follows. A goes to court B and invites $\mathrm{E}$ to attend. $\mathrm{E}$ declines, on the ground that he thinks B is biased in A's favor. Whereupon E, both them being reasonable men, ${ }^{14}$ returns the invitation to A, but only under the jurisdiction of court D. But A sees court D in much the same way as E views court B: biased against him. Whereupon, each of them make use of their own court. A signs on with $\mathrm{B}$, and $\mathrm{E}$ with $\mathrm{D}$. By sign on we mean, pays a fee, signs a contract to be bound by the decision of, etc. Each of these courts is associated with a private police organization, so as to compel A and E to comply with the judicial finding of $\mathrm{B}$ and $\mathrm{D}$, respectively.

There are now four possible outcomes:

1. B finds in favor of $A$

2. $B$ finds in favor of $E$

3. $D$ finds in favor of $E$

4. D finds in favor of $A$

Let us ignore alternatives 2 and 4, and focus on 1 and 3, the more interesting pair. Each court is true to its supposed bias, and rules on the side of the

14 Suppose one of them, but not both, refuses to have this claim adjudicated. He will then put himself at a sharp disadvantage, in which the court hears only the other side of the story. If the two of them decline adjudication, the private court system cannot function. 
person who chose him. What then? Rand says that the anarcho-capitalist must "blank out" at this point, because he has no answer to this conundrum. ${ }^{15}$ But, we have. And here 'tis: there are two types of private courts, legitimate ones, and illegitimate gangster courts. The first type will have anticipated this challenge. They will have signed an agreement with every other court of this type, dealing with just such an eventuality. How? By stipulating in advance that if ever any judge found himself disagreeing with another member of this industry, they will both call upon a third judge to be, in effect, the supreme court. The B and D courts will have drawn up a list of such judges, call him C in this case, and both agree to be bound by whatever he decides. This decision will trickle down to A and E, who are contractually obligated to go along with whatever B and D determine, and, in this case, they have agreed, in advance, to support the findings of $\mathrm{C}$.

What kind of judges will be selected in such a system? Magistrates known for their wisdom and fairness. People who, even if they rule against you, will be able to demonstrate that their decision was a reasonable one. Judges of the sort who will offer to cut babies in half. This is in sharp contrast to how members of the bench are now chosen; through a very imperfect political system. Under free enterprise, however, the leading judges will be selected in roughly the same manner as leading chefs, musicians, doctors, are now chosen; based on expertise, accomplishment, etc.

But what about the bandit courts? Their motto is, "my way or the highway." They do not recognize any higher authority. ${ }^{16}$ They will not likely survive in an anarcho-capitalist society, for several reasons. First, when they disagree with another desperado court they will have to fight. When they disagree with a licit court they will also have to fight. They will continually have to engage in violent hostile acts. On the other hand, legitimate courts will settle their differences with other judges of this ilk, peacefully, as we have seen. They will only have to take up arms against the hoodlums. Physical combat is expensive; it will tend to weed out mobster institutions. Second, the pen is mightier than the sword, in that it determines the direction in which the

15 See Ayn Rand, The Virtue of Selfishness (New York: Penguin, 1961).

16 In this case it is $\mathrm{C}$. But in the next dispute, it can be anyone chosen by members of this industry. 
former points. ${ }^{17}$ The thug judges will have no legitimacy. Everyone will likely be against them. Even dictators, at present, have to consider public opinion to some degree.

But suppose, just suppose, contrary to likelihood conditional, that bandit court(s) somehow beat out all the legitimate ones; it (they) in effect become the government. This is extremely implausible, but it cannot be ignored, since it does not constitute a logical contradiction. Murphy deals with this objection as follows:

When dealing with the warlord objection, we need to keep our comparisons fair. It won't do to compare society A, which is filled with evil, ignorant savages who live under anarchy, with society B, which is populated by enlightened, law-abiding citizens who live under limited government. The anarchist doesn't deny that life might be better in society $\mathrm{B}$. What the anarchist does claim is that, for any given population, the imposition of a coercive government will make things worse. The absence of a State is a necessary, but not sufficient, condition to achieve the free society. ${ }^{18}$

Murphy continues: "For the warlord objection to work, the statist would need to argue that a given community would remain lawful under a government, but that the same community would break down into continuous warfare if all legal and military services were privatized." ${ }^{19}$

When we recall just how many innocent people died under the rule of government, it is difficult to acquiesce in the notion that gangsters, reviled by all decent people, could do worse.

Then there is the objection that the wealthiest litigant would be able to prevail, by bribing the judge. This, too, is a serious objection. It is not an utter impossibility that this could occur. However, once this was found out, it would spell the death knell of any such court; virtually no one would approach it, seeking justice. It's only option would be to embrace banditry, and we have

17 In the view of Hummel: "Ideas, not brute force, rule the world. If you change people's minds, you change the direction in which they point their guns." Jeffrey Rogers Hummel, "A Practical Case for Denationalizing Defense", Part 2, The Pragmatist 3 (1986): 3.

18 Robert P. Murphy, “But Wouldn't Warlords Take Over?”, Mises Institute, 7.7.2005, access 8.7.2005, http://mises.org/story/1855; http://mises.org/library/wouldnt-warlords-take-over.

19 Ibidem. 
already covered that alternative. There are referees in sporting events such as swimming, track and field, baseball, football, tennis, basketball, boxing, handball, golf, etc. Often one team or individual is far richer than his, their competitor. Cases in which the judge-referee allowed himself to be swayed by any such consideration must be very near zero. Yes, they sometimes err, they are only human. But it is exceedingly rare they are bought off. The same is likely to occur under anarcho-capitalism.

This objection is a version of the claim that the rich will rule; but, they already do, under present institutional arrangements. Surely, they can hire better lawyers. The wealthy typically get the long end of the stick. ${ }^{20}$ One is always in a better position to bribe people if he is rich than if not; that is true. But, the wealthy would have less power in a market than in a government. Any court with the reputation of discriminating in favor of millionaires against the poor would soon be shown the exit, via bankruptcy. In contrast, government judges sometimes have tenure, or, at least, a term of several years before they can be shown the door, via the ballot box. The emperor's wife, must not only be pure, but be seen to be pure. The same applies to private judges.

There are numerous other services besides courts of which it is alleged that only government can provide. Roads, streets and highways are one such. But the first of these thoroughfares were privately built; they were not public. Trains and subways are another case in point. In New York City, the Interborough Rapid Transit (IRT) and the Borough of Manhattan Transit (BMT) companies were originally private; they were later nationalized, e.g., municipalized. ${ }^{21}$

It is the same with lighthouses. These are no longer needed, given that new GPS technology has overtaken the need for them, but it is important to demonstrate that anarcho-capitalism is the best and most viable system not only in the modern era, but was throughout all of recorded history. Coase maintained that only government would provide this benefit to shipping,

20 It is almost always good to be rich. The Mel Brooks movie "The history of the world, Part I," established that "it is good to be king."

${ }^{21}$ Walter E. Block, The Privatization of Roads and Highways: Human and Economic Factors (Auburn, AL: The Mises Institute, 2009). 
but he was wrong. ${ }^{22}$ The lighthouse owner had a viable threat against nonpayers; one of these days, when the evening sky was slightly illuminated, and none of his paying clients are out there at sea, he would shut down his operation. Sailing on the ships of these free riders would thus become dangerous, and their owners would have to offer higher hazard pay to their employees.

\section{Somalia}

Somalia is exhibit "A" in the case against anarchism. The country, it may readily be admitted, is as close to anarchism as any on the planet. It does not at all exemplify the libertarian variety thereof, but let that pass. Critics of anarcho-capitalism have been having a field day pointing to the shortcomings of this beleaguered African nation, using it as a stick with which to beat up on the philosophy defended in the present essay.

And, yes, Somalia has its share of problems, and more. This cannot be denied. When compared to more stable places such as England, Japan, Canada, this country comes off second best, indeed, a long way back.

However, that is not a proper comparison. Of course these western nations leave Somalia in the shade. It has more infant mortality, shortened life span, lower income, less wealth, higher crime rates, etc., than they do. But when compared not with England, Japan, Canada, etc., but rather with its neighboring nations in Africa, all of a sudden Somalia does not look quite as bad. Indeed, it is often just as good, and sometimes better, in terms of these statistical measurements. Powell has done yeoman work in demonstrating that when Somalia is compared to many of its fellow

${ }^{22}$ Ronald H. Coase. "The Lighthouse in Economics". Journal of Law and Economics 17 (1974): 357-376. Most scholars mistakenly think the very opposite; to wit, that this economist demonstrated that markets would suffice. For a correction, see William II Barnett, Walter E. Block, "Coase and Van Zandt on Lighthouses", Public Finance Review 35 (2007), 6: 710733; William II Barnett, Walter E. Block, "Coase and Bertrand on Lighthouses". Public Choice 140 (2009), 1-2:1-13; Walter E. Block, "Rejoinder to Bertrand on lighthouses", Romanian Economic and Business Review 6 (2011), 3: 49-67. 
African nations, it is not behind-hand at all. ${ }^{23}$ It is "as good as any, better than some."24

\section{Why do most economists reject anarcho-capitalism?}

First of all, although this academic discipline is perhaps the most oriented toward laissez faire, ${ }^{25}$ most professional economists are not even libertarians, let alone anarcho-capitalists. Why not? This is mainly because they support the notion of market failure. Here is a list of them: public goods or common-pool resources, transaction costs, agency problems, informational asymmetry, externalities, market power (monopoly), expectations, equity, underemployment equilibrium (Keynesianism). This is actually but the tip of the iceberg of so-called market failures. It would take us way too far afield to offer anything like a detailed criticism of many of them, let alone all of them. ${ }^{26}$ I content myself with briefly mentioning some criticisms of the

23 Benjamin Powell, "Somalia: Failed State, Economic Success?", The Freeman. Ideas on Liberty 59 (2009), 3. Also see C. Coyne, "Reconstructing weak and failed states: foreign intervention and the nirvana fallacy", Foreign Policy Analysis 2 (2006): 343-361; Peter T. Leeson, "Better off stateless: Somalia before and after government collapse", Journal of Comparative Economics 35 (2007), 4: 689-710; P. Little, Somalia: Economy Without State (Bloomington, IN: Indiana University Press, 2003); Eric S. Margolis, “Attacking Somalia Yet Again”, LewRockwell.com, 1.1.2007, access 9.11.2021, https:/www.lewrockwell.com/2007/01/eric-margolis/ attacking-somalia-yet-again/; K. Menkhaus, "State collapse in Somalia: second thoughts", Review of African Political Economy 97 (2003), 405-422; J. Mubarak, “The 'hidden hand' behind the resilience of the stateless economy of Somalia", World Development 25 (1997): 2027-2041; J. Mubarak, "A case of private supply of money in stateless Somalia", Journal of African Economies 11 (2002): 309-325; T. Nenova, T. Harford, Anarchy and Invention (Public Policy for the Private Sector: World Bank Group, 2004), note Number 280; Benjamin Powell, Ryan Ford, Alex Nowrasteh, "Somalia After State Collapse: Chaos or Improvement", Journal of Economic Behavior \& Organization 67 (2008), 3-4: 657-670; Murray N. Rothbard, “Doing God's Work' in Somalia”. Rothbard-Rockwell Report 4, 3. Burlingame, CA: Center for Libertarian Studies, 1993; M. Van Notten, The Law of the Somalis (Trenton, NJ: Red Sea Press, 2005).

24 This modest claim is sometimes used as an advertising slogan in the modern era: https:// www.tripadvisor.ca/ShowUserReviews-g57327-d4914080-r199381887-Green_Dragon-Morrisville_Vermont.html\#MAPVIEW; it was also used in the 1940s to promote a brand of milk.

${ }_{25}$ Sociology, anthropology, philosophy, literature, history, are far worse, to say nothing of the whining studies: black studies, feminist studies, queer studies, etc.

${ }^{26}$ It is only the Austrian School of economics that rejects this notion in its entirety. 
more prominent of these market failures: monopoly, ${ }^{27}$ externalities, public

27 Monopoly: William Anderson et al., "The Microsoft Corporation in Collision with Antitrust Law”, The Journal of Social, Political and Economic Studies 26 (2001), 1: 287-302; Dominick T. Armentano, The Myths of Antitrust (New Rochelle, N.Y.: Arlington House, 1972); Dominick T. Armentano, Antitrust and Monopoly: Anatomy of a Policy Failure (New York: Wiley, 1982); Dominick T. Armentano, "Antitrust Reform: Predatory Practices and the Competitive Process", Review of Austrian Economics 3 (1989): 61-74; Dominick T. Armentano, Antitrust: The Case for Repeal, Revised 2nd ed. (Auburn, AL: Mises Institute, 1999); Donald Armstrong, Competition versus Monopoly: Combines Policy in Perspective (Vancouver, BC Canada: The Fraser Institute, 1982); William Barnett, Walter E. Block, Michael Saliba, "Perfect Competition: A Case of 'Market-Failure". Corporate Ownership \& Control 2 (2005), 4: 70-75; William II Barnett, Walter E. Block, Michael Saliba, "Predatory pricing”, Corporate Ownership \& Control 4 (2007), 4: 401-406; Walter E. Block, „Austrian Monopoly Theory a Critique", The Journal of Libertarian Studies I (1977), 4: 271-279; Walter E. Block, Amending the Combines Investigation Act (Vancouver: The Fraser Institute, 1982); Walter E. Block, "Total Repeal of Anti-trust Legislation: A Critique of Bork, Brozen and Posner", Review of Austrian Economics 8 (1994), 1: 35-70; Walter E. Block, William Barnett, "Monopsony Theory", American Review of Political Economy 7 (2009), 1/2: 67-109; Donald J. Boudreaux, Thomas J. DiLorenzo, "The Protectionist Roots of Antitrust", Review of Austrian Economics 6 (1992), 2: 81-96; Diana Costea, "A Critique of Mises's Theory of Monopoly Prices", The Quarterly Journal of Austrian Economics 6 (2003), 3: 47-62; Thomas J. DiLorenzo, "The Myth of Natural Monopoly", Review of Austrian Economics 9 (1996), 2: 43-58; Thomas DiLorenzo, Jack High, "Antitrust and Competition, Historically Considered", Economic Inquiry 26 (1988), 1: 423-435; David R. Henderson, “The Robber Barons: Neither Robbers nor Barons”, Library of Economics and Liberty, 4.3.2013, access 9.11.2021, http://www.econlib.org/cgi-bin/printarticle2.pl?file=Columns/y2013/Hendersonbarons.html; Jack High, "Bork's Paradox: Static vs Dynamic Efficiency in Antitrust Analysis", Contemporary Policy Issues 3 (1984-1985): 21-34; Gary Hull, ed., The Abolition of Antitrust (New Brunswick, NJ: Transaction Publishers, 2005); Fred McChesney, "Antitrust and Regulation: Chicago's Contradictory Views", Cato Journal 10 (1991), 3: 775-798; John S. McGee, "Predatory Price Cutting: The Standard Oil (New Jersey) Case", The Journal of Law and Economics October 1958: 137-169; Murray N. Rothbard, Man, Economy and State. Scholar's Edition (Auburn, AL: Ludwig von Mises Institute, 2004 [1962]); William II F. Shugart, “Don't Revise the Clayton Act, Scrap It!”, Cato Journal 6 (1987): 925; Fred Jr. L. Smith, "Why not Abolish Antitrust?", Competitive Enterprise Institute, 31.12.1982, access 9.11.2021, http://cei.org/op-eds-and-articles/why-not-abolish-antitrust; Jeffrey Tucker, “Controversy: Are Antitrust Laws Immoral?”, Journal of Markets \& Morality 1 (1998), 1: 75-82; Jeffrey Tucker, "Controversy: Are Antitrust Laws Immoral? A Response to Kenneth G. Elzinga”, Journal of Markets \& Morality 1 (1998), 1: 90-94. 
$\operatorname{goods}^{28}$ and business cycles. ${ }^{29}$

${ }^{28}$ Externalities, Public Goods: William II Barnett, Walter E. Block, "Coase and Van Zandt on Lighthouses", Public Finance Review 35 (2007), 6: 710-733; William II Barnett, Walter E. Block, "Coase and Bertrand on Lighthouses". Public Choice 140 (2009), 1-2:1-13; Walter E. Block, "Public Goods and Externalities: The Case of Roads", The Journal of Libertarian Studies: An Interdisciplinary Review VII (1983), 1: 1-34; Walter E. Block, "Word Watch", Mises Daily, 20.4.2000, access 9.11.2021, http://www.mises.org/fullstory. asp? control=414\&FS=Word+Watch; Walter E. Block, "National Defense and the Theory of Externalities, Public Goods and Clubs" in: The Myth of National Defense: Essays on the Theory and History of Security Production, ed. Hans-Hermann Hoppe (Auburn: Mises Institute, 2003), 301-334; Tyler Cowen, ed., The Theory of Market Failure: A Critical Examination (Fairfax, VA: George Mason University Press, 1988); Anthony De Jasay, Social Contract, Free Ride: A Study of the Public Goods Problem (Oxford, England: Oxford University Press, 1989); Randall Holcombe, "A Theory of the Theory of Public Goods", Review of Austrian Economics 10 (1997), 1: 1-10; Hans-Hermann Hoppe, "Fallacies of the Public Goods Theory and the Production of Security”, The Journal of Libertarian Studies IX (1989), 1: 27-46; Jeffrey Hummel, „National Goods vs. Public Goods: Defense, Disarmament and Free Riders", The Review of Austrian Economics IV (1990): 88-122; David Osterfeld, "Anarchism and the Public Goods Issue: Law, Courts and the Police", The Journal of Libertarian Studies 9 (1989), 1: 47-68; E.C. Jr. Pasour, "The Free Rider as a Basis for Government Intervention", The Journal of Libertarian Studies V (1981), 4: 453-464; Gerard Radnitzky, "Review of De Jasay Anthony. 1989. Social Contract, Free Ride: A Study of the Public Goods Problem”, Cato Journal 9 (1989), 1: 263-270; Murray N. Rothbard, The Logic of Action: Applications and Criticism from the Austrian School, Vol. II (Cheltenham, UK: Edward Elgar, 1997); David Schmidtz, The Limits of Government: An Essay on the Public Goods Argument (Boulder Co: Westview Press, 1991); Larry Sechrest, "Privateering and National Defense: Naval Warfare for Private Profit", in: The Myth of National Defense: Essays on the Theory and History of Security Production, ed. Hans-Hermann Hoppe (Auburn, AL: Ludwig von Mises Institute, 2003), 239-274; Larry Sechrest, "Public Goods and Private Solutions in Maritime History”, The Quarterly Journal of Austrian Economics 7 (2004), 2: 3-27; Larry Sechrest, "Private Provision of Public Goods: Theoretical Issues and Some Examples from Maritime History", ICFAI Journal of Public Finance II (2004), 3: 45-73; Larry Sechrest, "Privately Funded and Built U.S. Warships in the Quasi-War of 1797-1801", The Independent Review 12 (2007), 1: 101-113; Patrick Tinsley, "With Liberty and Justice for All: A Case for Private Police", Journal of Libertarian Studies 14 (1998-1999), 1: 95-100.

29 Business Cycles: William II Barnett, Walter E. Block, Essays in Austrian Economics (New York: Ishi Press, 2012); Roger W. Garrison, Time and Money: The Macroeconomics of Capital Structure (London: Routledge, 2001); Friedrich A. Hayek, Prices and Production (London: Routledge, 1931); Ludwig von Mises, The Theory of Money and Credit (New Haven, CT: Yale 
Monopoly first. As Rothbard demonstrated, adherents of this view cannot even unambiguously distinguish between a monopoly price and a non-monopoly price, one that arises without a government grant of privilege. ${ }^{30}$ Also, the main criticism of large scale enterprises which arise on the free market from this quarter is that they "withhold" a quantity of the product they offer in order to boost prices and profits, but the critics never supply a criterion on the basis of which such a claim can be verified. Such a company only supplies X amount; they claim he should offer $\mathrm{X}+\mathrm{Y}$, totally in the absence of any proof thereof.

Positive externalities or external economies are not a market failure at all. I smile at you, or take a shower. I benefit you. ${ }^{31}$ But, I am not allowed to charge you for this goodness on my part. Therefore, I will do less of it than if I were allowed to make you pay against your will, for a "service" you did not wish to purchase. Rothbard puts paid to this notion as follows:

A and B often benefit, it is held, if they can force $\mathrm{C}$ into doing something. [...] $[A] n y$ argument proclaiming the right and goodness of, say, three neighbors, who yearn to form a string quartet, forcing a fourth neighbor at bayonet point to learn and play the viola, is hardly deserving of sober comment. ${ }^{32}$

This author is no kinder to the doctrine of negative externalities, or external diseconomies. The most high profile of the complaints in this regard is smoke pollution. But Rothbard blows this one out of the water with his

University Press, [1912] 1953); Ludwig von Mises, Human Action, Scholars' Edition (Auburn: Mises Institute, [1949] 1998); Murray N. Rothbard, "Society Without a State", The Libertarian Forum 7 (1975), 1; Murray N. Rothbard, “Doing God's Work' in Somalia”, RothbardRockwell Report 4, 3. (Burlingame, CA: Center for Libertarian Studies, 1993); Frank Shostak, "Changes in the Money Supply Don't Cause Business Cycles", Mises Institute, 30.5.2017, access 9.11.2021, https://mises.org/blog/changes-money-supply-dont-cause-business-cycles; Thomas E. Jr. Woods, Meltdown: A Free-Market Look at Why the Stock Market Collapsed, the Economy Tanked, and Government Bailouts Will Make Things Worse (Washington, D.C.: Regnery Publishing, 2009).

${ }_{30}$ See Murray N. Rothbard, Man, Economy, and State: A Treatise on Economic Principles (Princeton, NJ: David van Nostrand Company/William Volker Fund, 1962).

31 Or not. Perhaps you don't like being smiled at.

32 Murray N. Rothbard, "Robert Nozick and the immaculate conception of the state", The Journal of Libertarian Studies 1 (1977), 1: 178. 
analysis. ${ }^{33}$ This is a violation of private property rights, a trespass of dust particles, not a market failure. It is, rather, a criminal act.

Public goods. According to this dogma, there are certain goods and services, e.g., police, military, lighthouses, that the market simply cannot produce at all, or, if it does, it will do so to a far less degree than optimal. As against this notion, there is no example ever offered, certainly not the three just mentioned, that have not been supplied at all on a profit-making basis. As to the claim that when so, not in sufficient amounts, no criteria to determine the truth or falsity of this claim has ever been forthcoming. Orthodox economists cannot point to the optimal amount.

\section{Depressions, inflation}

In the mainstream view, the free market economy is forever veering from massive unemployment to heavy inflation and back again. The goal of the government is to steer the economic ship onto the straight and narrow path, avoiding both these extremes. In the view of Austrian economics, the reason for this teeter-tottering emanate not from free enterprise, but, from the very institutions, government central banks, the Fed, supposedly set up to cure this malady in the first place.

\section{Nozick’s critique}

Perhaps the most philosophically sophisticated rejections of anarchocapitalism has been offered by Nozick. ${ }^{34} \mathrm{He}$ argues that private protection agencies will become a de facto government, purely through market forces, without any rights violations occurring whatsoever during this process. In other words, this system is unstable. Even while adhering, fully, to its strictures, anarcho-capitalism will evolve into a statist system. Yes, it will become a very limited government, e.g., an ultra minimal night-watchman state, but a government nevertheless. How will this occur? To make a long story short,

${ }^{33}$ See Murray N. Rothbard, "Law, Property Rights, and Air Pollution", Cato Journal 2 (1982), 1. Reprinted in Walter E. Block, ed., Economics and the Environment: A Reconciliation (Vancouver: The Fraser Institute, 1990).

${ }^{34}$ See Robert Nozick, Anarchy, State and Utopia (New York: Basic Books, 1974). 
one of the market defense agencies will become dominant. Through market forces, one of them will come occupy a greater and greater share of the market, via efficiency. Then, it will have the obligation to protect its clients from the improper court procedures of its smaller competitors. But, if it does so, it will also be obliged to protect their clients as well.

There is more wrong in this thesis than you can shake a stick at. This eminent philosopher offers no evidence, or reason, to assume there will be a dominant free market defense agency. In many industries, there is a big three, or a big five. It is extremely rare that there would be only a big one, without government favoritism. Or, if this does occur, IBM is the best example, that its single seller status will long endure. Another difficulty is that there is no reason to suppose any positive correlation between reliable methods of determining truth and ferreting out justice, on the one hand, and large size on the other. The dominant firm (if one ensues, and lasts) is not any more justified in compelling its smaller competitors to adopt its court room methods, than the reverse. Then there is the problem that if the dominant agency restricts its colleagues from operation, even if it compensates them, this is hardly consonant with the NAP. ${ }^{35}$

\section{Conclusion}

I cannot do any better for an end to this essay than to quote the most brilliant advocate of anarcho-capitalism:

In the view of Rothbard:

35 For critics of Nozick's dismissal of anarcho-capitalism, see: Randy Barnett, "Whither anarchy? Has Robert Nozick justified the state?", The Journal of Libertarian Studies 1 (1977), 1: 15-22; Walter E. Block, "The Libertarian Minimal State? A critique of the views of Nozick, Levin and Rand", Journal of Ayn Rand Studies 4 (2002), 1: 141-160; Roy A. Jr. Childs, “The invisible hand strikes back", The Journal of Libertarian Studies 1 (1977), 1: 23-34; Williamson M. Evers, "Toward a reformulation of the law of contracts", The Journal of Libertarian Studies 1 (1977), 1: 3-14; Murray N. Rothbard, "Robert Nozick and the immaculate conception of the state", The Journal of Libertarian Studies 1 (1977), 1: 45-58; John T. Sanders, "The free market model versus Government: a reply to Nozick", The Journal of Libertarian Studies 1 (1977), 1: 35-44. 
For centuries, the State (or more strictly, individuals acting in their roles as 'members of the government') has cloaked its criminal activity in high-sounding rhetoric. For centuries the State has committed mass murder and called it 'war'; then ennobled the mass slaughter that 'war' involves. For centuries the State has enslaved people into its armed battalions and called it 'conscription' in the 'national service.' For centuries the State has robbed people at bayonet point and called it 'taxation.' In fact, if you wish to know how libertarians regard the State and any of its acts, simply think of the State as a criminal band, and all of the libertarian attitudes will logically fall into place. ${ }^{36}$

\section{References}

Anderson Terry L., P. J. Hill. 1979. "An American Experiment in Anarcho-Capitalism: The Not So Wild, Wild West". Journal of Libertarian Studies 3: 9-29.

Anderson Terry L., P. J. Hill. 2004. The Not So Wild, Wild West: Property Rights on the Frontier. Stanford, Calif.: Stanford University Press.

Anderson William, Walter E. Block, Thomas J. DiLorenzo, Ilana Mercer, Leon Snyman, Christopher Westley. 2001. "The Microsoft Corporation in Collision with Antitrust Law". The Journal of Social, Political and Economic Studies 26, 1: 287-302.

Armentano Dominick T. 1972. The Myths of Antitrust. New Rochelle, N.Y.: Arlington House.

Armentano Dominick T. 1982. Antitrust and Monopoly: Anatomy of a Policy Failure, New York: Wiley.

Armentano Dominick T. 1989. "Antitrust Reform: Predatory Practices and the Competitive Process". Review of Austrian Economics 3: 61-74.

Armentano Dominick T. 1999. Antitrust: The Case for Repeal. Revised 2nd ed., Auburn, AL: Mises Institute.

Armstrong Donald. 1982. Competition versus Monopoly: Combines Policy in Perspective. Vancouver, BC Canada: The Fraser Institute.

Barnett Randy. 1977. "Whither anarchy? Has Robert Nozick justified the state?". The Journal of Libertarian Studies 1, 1: 15-22.

Barnett William II, Walter E. Block. 2007. "Coase and Van Zandt on Lighthouses". Public Finance Review 35, 6: 710-733.

Barnett William II, Walter E. Block. 2009. "Coase and Bertrand on Lighthouses". Public Choice 140, 1-2:1-13.

${ }^{36}$ Murray N. Rothbard, For a New Liberty (New York: Macmillan, 1973). 
Barnett William II, Walter E. Block. 2012. Essays in Austrian Economics. New York: Ishi Press.

Barnett William II, Walter E. Block, Michael Saliba. 2005. "Perfect Competition: A Case of 'Market-Failure". Corporate Ownership \& Control 2, 4: 70-75.

Barnett William II, Walter E. Block, Michael Saliba. 2007. "Predatory pricing". Corporate Ownership \& Control 4, 4: 401-406.

Benson Bruce L. 1989. "Enforcement of Private Property Rights in Primitive Societies: Law Without Government". The Journal of Libertarian Studies IX, 1: 1-26.

Benson Bruce L. 1990. "Customary Law with Private Means of Resolving Disputes and Dispensing Justice: A Description of a Modern System of Law and Order without State Coercion". The Journal of Libertarian Studies IX, 2: 25-42.

Block Walter E. 1977. "Austrian Monopoly Theory - a Critique". The Journal of Libertarian Studies I, 4: 271-279.

Block Walter E. 1982. Amending the Combines Investigation Act. Vancouver: The Fraser Institute.

Block Walter E. 1982. "Economic Intervention, Discrimination and Unforeseen Consequences". In: Discrimination, Affirmative Action and Equal Opportunity, ed. Walter E. Block, Michael A. Walker, 101-125. Vancouver: The Fraser Institute.

Block Walter E. 1983. "Public Goods and Externalities: The Case of Roads". The Journal of Libertarian Studies: An Interdisciplinary Review VII, 1: 1-34.

Block Walter E. 1985. "Directions for Future Research in Equal Pay Legislation". In: Towards Equity: Proceedings of a Colloquium on the Economic Status of Women in the Labour Market, ed. Muriel Armstrong, 119-121, 134-135, 179-182. Ottawa: The Economic Council.

Block Walter E. 1992. "Discrimination: An Interdisciplinary Analysis". The Journal of Business Ethics 11: 241-254.

Block Walter E. 1994. "Total Repeal of Anti-trust Legislation: A Critique of Bork, Brozen and Posner". Review of Austrian Economics 8, 1:35-70.

Block Walter E. 1998. "Compromising the Uncompromisable: Discrimination". American Journal of Economics and Sociology 57, 2: 223-237.

Block Walter E. “Word Watch". Mises Daily, 20.4.2000. Access 9.11.2021. http://www. mises.org/fullstory.asp?control=414\&FS=Word+Watch.

Block Walter E. 2002. "The Libertarian Minimal State? A critique of the views of Nozick, Levin and Rand". Journal of Ayn Rand Studies 4, 1: 141-160.

Block Walter E. 2003. "National Defense and the Theory of Externalities, Public Goods and Clubs". In: The Myth of National Defense: Essays on the Theory and History of Security Production, ed. Hans-Hermann Hoppe, 301-334. Auburn: Mises Institute. 
Block Walter E. "Deaths by Government: Another Missing Chapter". LewRockwell. com, 27.11.2006. Access 9.11.2021. https://www.lewrockwell.com/2006/11/walter-e-block/deaths-by-government-anothermissingchapter/.

Block Walter E. 2007. "Anarchism and Minarchism; No Rapprochement Possible". Journal of Libertarian Studies 21, 1: 91-99.

Block Walter E. 2009. The Privatization of Roads and Highways: Human and Economic Factors. Auburn, AL: The Mises Institute.

Block Walter E. 2011. "Governmental inevitability: reply to Holcombe". Journal of Libertarian Studies 22: 667-688.

Block Walter E. 2011. "Rejoinder to Bertrand on lighthouses". Romanian Economic and Business Review 6, 3: 49-67.

Block Walter E., William Barnett. 2009. "Monopsony Theory". American Review of Political Economy 7, 1/2: 67-109.

Block Walter E., Michael Fleischer. "How Would An Anarchist Society Handle Child Abuse?”. LewRockwell.com, 13.10.2010. Access 9.11.2021. http://www.lewrockwell.com/block/block167.html.

Block Walter E., Nicholas Snow, Edward Stringham. 2008. "Banks, Insurance Companies and Discrimination”. Business and Society Review 113, 3: 403-419.

Block Walter, Michael A. Walker. 1985. Focus on Employment Equity: A Critique of the Abella Royal Commission on Equality in Employment. Vancouver: The Fraser Institute.

Block Walter, Williams Walter E. 1981. "Male-Female Earnings Differentials: A Critical Reappraisal". The Journal of Labor Research II, 2: 385-388.

Boudreaux Donald J., Thomas J. DiLorenzo. 1992. "The Protectionist Roots of Antitrust". Review of Austrian Economics 6, 2: 81-96.

Branfman Fred. "World's Most Evil and Lawless Institution? The Executive Branch of the U.S. Government". Alternet, 26.6.2013. Acces 9.11.2021. http://www.alternet.org/investigations/executive-branch-evil-and-lawless?paging=off.

Casey Doug. "Doug Casey on Anarchy”. Casey Research, 31.3.2010. Access 1.4.2010. http://www.caseyresearch.com/cwc/doug-casey-anarchy.

Casey Gerard. 2012. Libertarian Anarchy: Against the State. Bloomsbury Academic.

Childs Roy A. Jr. 1977. "The invisible hand strikes back". The Journal of Libertarian Studies 1, 1: 23-34.

Chomsky Noam. 1977. Language and Responsibility. New York: Pantheon Books.

Chomsky Noam. 1981. Radical Priorities. Montreal: Black Rose Books.

Chomsky Noam. 1987. On Power and Ideology. Boston: South End Press.

Chomsky Noam. 2005. "Simple truths, hard problems: Some thoughts on terror, justice, and self-defence". Philosophy 80: 5-28.

Chomsky Noam. 2008. "Humanitarian imperialism: The new doctrine of imperial right". Monthly Review 60: 22-50. 
Chomsky Noam. "Noam Chomsky on US Libertarian Party". You Tube, 24.11.2011. Access 9.11.2021. http://www.youtube.com/watch?v=gbL3zRgZUBo.

Cowen Tyler, ed. 1988. The Theory of Market Failure: A Critical Examination. Fairfax, VA: George Mason University Press.

Coyne C., 2006. "Reconstructing weak and failed states: foreign intervention and the nirvana fallacy". Foreign Policy Analysis 2: 343-361.

Coase Ronald H. 1974. "The Lighthouse in Economics". Journal of Law and Economics 17: 357-376.

Conquest Robert. 1986. The Harvest of Sorrow. New York: Oxford University Press.

Conquest Robert. 1990. The Great Terror. Edmonton, Alberta: Edmonton University Press.

Costea Diana. 2003. “A Critique of Mises's Theory of Monopoly Prices”. The Quarterly Journal of Austrian Economics 6, 3: 47-62.

Courtois Stephane, Nicolas Werth, Jean-Louis Panne, Andrzej Paczkowski, Karel Bartosek, Jean Louis Margolin. 1999. The Black Book of Communism: Crimes, Terror, Repression, transl. Jonathan Murphy, Mark Kramer. Cambridge, MA: Harvard University Press.

De Jasay Anthony. 1989. Social Contract, Free Ride: A Study of the Public Goods Problem. Oxford, England: Oxford University Press.

DiLorenzo Thomas J. 1996. "The Myth of Natural Monopoly". Review of Austrian Economics 9, 2: 43-58.

DiLorenzo Thomas. "Death by Government: The Missing Chapter". LewRockwell. com, 22.11.2006. Access 9.11.2021. http://www.lewrockwell.com/dilorenzo/ dilorenzo114.html.

DiLorenzo Thomas J. 2010. "The Culture of Violence in the American West: Myth versus Reality”. The Independent Review 15, 2: 227-239.

DiLorenzo, Tom and Jack High. 1988. "Antitrust and Competition, Historically Considered", Economic Inquiry 26, 1: 423-435.

Ebeling Richard M. "The human cost of socialism in power". The Future of Freedom Foundations, 9.9.2015. Access 9.11.2021. https://www.fff.org/explore-freedom/ article/the-human-cost-of-socialism-in-power/.

England Randy. “The state: what can we replace it with?". LewRockwell.com, 31.3.2013. Access 9.11.2021. http://www.lewrockwell.com/blog/lewrw/archives/134782. html.

Evers Williamson M. 1977. "Toward a reformulation of the law of contracts". The Journal of Libertarian Studies 1, 1: 3-14.

Garrison Roger W. 2001. Time and Money: The Macroeconomics of Capital Structure. London: Routledge.

Gregory Anthony. "Abolish the Police". LewRockwell.com, 26.5.2011. Access 9.11.2021. http://www.lewrockwell.com/gregory/gregory213.html. 
Guillory Gil, Patrick Tinsley. 2009. “The Role of Subscription-Based Patrol and Restitution in the Future of Liberty". Libertarian Papers 1, 12: 1-40.

Gottfredson Linda S. 1986. "Societal consequences of the g factor in employment". Journal of Vocational Behavior 29: 379-410.

Hasnas John. 1995. "The myth of the rule of law". Wisconsin Law Review 199.

Hayek Friedrich A. 1931. Prices and Production. London: Routledge.

Heinrich David J. "Justice for All Without the State". The Libertarian Standard, 6.5.2010. Access 9.11.2021. http://www.libertarianstandard.com/articles/davidj-heinrich/justice-for-all-without-the-state/.

Henderson David R. "The Robber Barons: Neither Robbers nor Barons". Library of Economics and Liberty, 4.3.2013. Access 9.11.2021. http://www.econlib.org/ cgi-bin/printarticle2.pl?file=Columns/y2013/Hendersonbarons.html.

Herrnstein Richard J., Murray Charles. 1994. The Bell Curve: Intelligence and Class Structure in American Life. New York: The Free Press.

Higgs Robert. "Why We Couldn't Abolish Slavery Then and Can't Abolish Government Now". LewRockwell.com, 20.8.2009. Access 9.11.2021. http://www.lewrockwell.com/higgs/higgs128.html.

Higgs Robert. "What is the point of my libertarian anarchism?". LewRockwell.com, 16.1.2012. Access 9.11.2021. http://archive.lewrockwell.com/higgs/higgs180. html.

Higgs Robert. "The State-Crown Jewel of Human Social Organization". LewRockwell.com, 13.7.2013. Access 14.7.2013. http://www.lewrockwell.com/blog/lewrw/archives/135000.html.

High Jack. 1984-1985. "Bork's Paradox: Static vs Dynamic Efficiency in Antitrust Analysis". Contemporary Policy Issues 3: 21-34.

Holcombe Randall. 1997. "A Theory of the Theory of Public Goods". Review of Austrian Economics 10, 1: 1-10.

Hoppe Hans-Hermann. 1989. "Fallacies of the Public Goods Theory and the Production of Security". The Journal of Libertarian Studies IX, 1:27-46.

Hoppe Hans-Hermann. 2001. Democracy - The God That Failed: The Economics and Politics of Monarchy, Democracy, and Natural Order. Rutgers University, N.J.: Transaction Publishers.

Hoppe Hans-Hermann. "Reflections on the Origin and the Stability of the State". LewRockwell.com, 23.6.2008. Access 9.11.2021. http://www.lewrockwell.com/ hoppe/hoppe18.html.

Hoppe Hans-Hermann. "State or Private Law Society". LewRockwell.com, 10.4.2011. Access 9.11.2021. http://www.lewrockwell.com/hoppe/hoppe26.1.html.

Huebert Jacob. 2010. Libertarianism Today. Santa Barbara, CA: Praeger.

Hull Gary, ed. 2005. The Abolition of Antitrust. New Brunswick, NJ: Transaction Publishers. 
Hummel Jeffrey Rogers. 1986. "A Practical Case for Denationalizing Defense”, Part 2, The Pragmatist 3.

Hummel Jeffrey. 1990. "National Goods vs. Public Goods: Defense, Disarmament and Free Riders". The Review of Austrian Economics IV: 88-122.

Jensen Arthur R. 1981. Straight Talk about Mental Tests. New York: Free Press.

King Seth. "Daily Anarchist Interviews Walter E. Block". LewRockwell.com, 9.9.2010. Access 9.11.2021. http://www.lewrockwell.com/block/block165.html.

Kinsella Stephan. "The Irrelevance of the Impossibility of Anarcho-Libertarianism". StephanKinsella.com, 20.8.2009. Access 9.11.2021. http://www.stephankinsella. com/2009/08/20/the-irrelevance-of-the-impossibility-of-anarcho-libertarianism/.

Leeson Peter T. 2007. "Better off stateless: Somalia before and after government collapse”. Journal of Comparative Economics 35, 4: 689-710.

Little P., 2003. Somalia: Economy Without State. Bloomington, IN: Indiana University Press.

Locke John. 1960. An Essay Concerning the True Origin, Extent and End of Civil Government. In: John Locke, Two Treatises of Government, ed. P. Laslett. Cambridge: Cambridge University Press.

Levendis John, Walter E. Block, Robert B. Eckhardt. 2019. "Evolutionary psychology, economic freedom, trade and benevolence". Review of Economic Perspectives Národohospodářský obzor 19, 2: 73-92.

Levin Michael. 1987. Feminism and Freedom. New York: Transaction Books.

Levin Michael. 1997. Why Race Matters: Race Differences and What They Mean. New York: Praeger Publishers.

Long Roderick. "Libertarian Anarchism: Responses to Ten Objections". LewRockwell. com, 19.8.2004. Access 9.11.2021. http://www.lewrockwell.com/long/long11. html.

Lynn Richard, Tatu Vanhanen. 2002. IQ And The Wealth Of Nations. New York, N.Y.: Praeger Publishers.

Lynn Richard, Tatu Vanhanen. 2006. IQ and Global Inequality. Washington: Summit Publishers.

McConkey Michael. 2013. "Anarchy, Sovereignty, and the State of Exception: Schmitt's Challenge". The Independent Review 17, 3: 415-428.

Molyneux Stefan. "The Stateless Society: An Examination of Alternatives". The Mail Archive, 1.2.2008. Access 9.11.2021. http://www.mail-archive.com/libertarianenterprise@yahoogroups.com/msg02056.html.

Molyneux Stefan versus Michael Badnarik. "How much government is necessary". Freedomain, 5.7.2009. Access 9.11.2021. http://www.freedomainradio.com/Videos.aspx. 
Murphy Robert P. “But Wouldn't Warlords Take Over?". Mises Institute, 7.7.2005. Access 8.7.2005. http://mises.org/story/1855; http://mises.org/library/wouldntwarlords-take-over.

Murphy Robert P. "Overrating Government Service". Mises Institute, 15.3.2010. Access 9.111.2021. http://mises.org/daily/4131?utm_source=Ludwig+von+Mises+ Institute + of + Canada + Daily + List \&utm_campaign $=e 4794$ b $19 \mathrm{~d} 8-$ RSS EMAIL_CAMPAIGN\&utm_medium $=$ email\&utm_term $=0 \_6 \mathrm{c} 2$ fea3584e4794b19d8-274221537.

Murphy Robert P. "Where Are the Rothbardian Defense Agencies?". Mises Institute, 14.12.2013. Access 15.12.2013. https://www.mises.ca/where-are-the-rothbardian-defense-agencies.

Murphy Robert P. "Drug Gangs and Private Law". Mises Institute, 17.12.2013. Access 9.11.2021. http://mises.ca/posts/blog/drug-gangs-and-private-law/.

Murphy Robert P. "Randians versus Rothbardians". Mises Institute, 22.12.2014. Access 9.11.2021. http://mises.ca/posts/blog/randians-versus-rothbardians/.

MacDonald Heather. 2018. The Diversity Delusion: How Race and Gender Pandering Corrupt the University and Undermine Our Culture. New York: St. Martin's Press.

Margolis Eric S., "Attacking Somalia Yet Again". LewRockwell.com, 1.1.2007. Access 9.11.2021. https://www.lewrockwell.com/2007/01/eric-margolis/attacking-somalia-yet-again/.

McChesney Fred. 1991. "Antitrust and Regulation: Chicago's Contradictory Views". Cato Journal 10, 3: 775-798.

McGee John S. 1958. "Predatory Price Cutting: The Standard Oil (New Jersey) Case". The Journal of Law and Economics October: 137-169.

McMaken Ryan. "The Trouble with „Public Accommodation”. Mises Institute, 3.6.2016. Access 9.11.2021. https://mises.org/wire/trouble-public-accommodation.

Mercer Ilana. "The Silly Sex". V-Dare.com, 6.1.2005. Access 9.11.2021. http://www. vdare.com/misc/mercer_050106_silly.htm.

Menkhaus K. 2003. "State collapse in Somalia: second thoughts". Review of African Political Economy 97, 405-422.

Mises Ludwig von. [1912] 1953. The Theory of Money and Credit [originally published in German in 1912]. New Haven, CT: Yale University Press.

Mises Ludwig von. [1949] 1998. Human Action, Scholars' Edition. Auburn: Mises Institute.

Mubarak J., 1997. “The 'hidden hand' behind the resilience of the stateless economy of Somalia". World Development 25: 2027-2041.

Mubarak J. 2002. "A case of private supply of money in stateless Somalia". Journal of African Economies 11: 309-325. 
Murray Charles. "Jewish Genius". Commentary, April 2007. Access 9.11.2021. https:// www.commentary.org/articles/charles-murray/jewish-genius/.

Nenova T., Harford T. 2004. Anarchy and Invention. Public Policy for the Private Sector: World Bank Group.

Nozick Robert. 1974. Anarchy, State and Utopia. New York: Basic Books.

Osterfeld David. 1989. "Anarchism and the Public Goods Issue: Law, Courts and the Police". The Journal of Libertarian Studies 9, 1: 47-68.

Ostrowsky James. "Chomsky's Economics". Mises Institute, 6.1.2003. Access 9.11.2021. https://mises.org/library/chomskys-economics.

Pasour Jr. E. C. 1981, “The Free Rider as a Basis for Government Intervention”. The Journal of Libertarian Studies V, 4: 453-464.

Paul Ron. You Tube, Undated. http://www.youtube.com/watch?v=7o4kiWpqoeg\& feature $=$ PlayList $\& \mathrm{p}=9645 \mathrm{~F} 6$ A68683F679\&playnext $=1 \&$ playnext_from $=$ PL\&index $=4$.

Powell Benjamin. 2009. "Somalia: Failed State, Economic Success?". The Freeman. Ideas on Liberty 59, 3.

Powell Benjamin, Ryan Ford, Alex Nowrasteh. 2008. "Somalia After State Collapse: Chaos or Improvement”. Journal of Economic Behavior \& Organization 67, 3-4: 657-670.

Radnitzky Gerard. 1989. "Review of De Jasay Anthony. 1989. Social Contract, Free Ride: A Study of the Public Goods Problem". Cato Journal 9, 1: 263-270.

Rand Ayn. 1961. The Virtue of Selfishness. New York: Penguin.

Rockwell Jr., Llewellyn H. 2014. Against the State: An Anarcho-Capitalist Manifesto. Auburn, AL: Rockwell Communications LLC.

Rockwell Jr., Llewellyn H. "What Libertarianism Is, and Isn't". LewRockwell.com, 31.3.2014. Access 9.11.2021. http://www.lewrockwell.com/2014/03/lew-rockwell/what-libertarianism-is-and-isnt/.

Rothbard Murray N. 1962. Man, Economy, and State: A Treatise on Economic Principles. Princeton, NJ: David van Nostrand Company/William Volker Fund.

Rothbard Murray N. [1963] 1975. America's Great Depression. Kansas City: Sheed and Ward.

Rothbard Murray N. 1973. For a New Liberty. New York: Macmillan.

Rothbard Murray N. 1975. "Society Without a State". The Libertarian Forum 7, 1.

Rothbard Murray N. 1977. "Do you hate the state?". The Libertarian Forum 10, 7.

Rothbard Murray N. 1977. "Robert Nozick and the immaculate conception of the state". The Journal of Libertarian Studies 1, 1: 45-58.

Rothbard Murray N. 1982. "Law, Property Rights, and Air Pollution". Cato Journal 2 , 1.Reprinted in Block Walter E, ed. 1990. Economics and the Environment: A Reconciliation. Vancouver: The Fraser Institute. 
Rothbard Murray N. 1993. "'Doing God's Work' in Somalia”. Rothbard-Rockwell Report 4, 3. Burlingame, CA: Center for Libertarian Studies.

Rothbard Murray N. 1997. The Logic of Action: Applications and Criticism from the Austrian School, Vol. II. Cheltenham, UK: Edward Elgar.

Rothbard Murray N. 1998. The Ethics of Liberty, New York: New York University Press.

Rothbard, Murray N. (2004 [1962]). Man, Economy and State. Scholar's Edition. Auburn, AL: Ludwig von Mises Institute.

Rummel R. J. 1992. Democide: Nazi Genocide and Mass Murder. Rutgers, New Jersey: Transaction Publisher.

Rummel R.J.1994.Death By Government.New Brunswick,NJ:Transaction.http:// www.hawaii.edu/powerkills/NOTE1.HTM; http://www.hawaii.edu/power kills/20TH.HTM.

Rummel R. J. 1997. Statistics on Democide. Charlottesville, VA: Center on National Security and Law, University of Virginia.

Rushton J. Philippe. 1988. "The reality of racial differences: A rejoinder with new evidence". Personality and Individual Differences 9: 1035-1040.

Rushton J. Philippe. 1991. "Reply to Wilerman on Mongoloid-Caucasoid Differences in Brain Size". Intelligence 15: 365-367.

Rushton J. Philippe. 1996. "Brain size and cognitive ability: Correlations with age, sex, social class and race". Psychonomic Bulletin and Review 3, 1:21-36.

Rushton J. Philippe, C. D. Ankney. 1993. "The evolutionary selection of human races: A response to Miller". Personality and Individual Differences 15: 677-680.

Rushton J. Philippe, R. T. Osborne. 1995. "Genetic and environmental contributions to cranial capacity estimated in Black and White adolescents". Intelligence 20: $1-13$.

Sanders John T. 1977. "The free market model versus Government: a reply to Nozick". The Journal of Libertarian Studies 1, 1: 35-44.

Schmidtz David. 1991. The Limits of Government: An Essay on the Public Goods Argument. Boulder Co: Westview Press.

Schumpeter Joseph A. 1942. Capitalism, Socialism and Democracy. New York: Harper.

Sechrest Larry. 2003. "Privateering and National Defense: Naval Warfare for Private Profit". In: The Myth of National Defense: Essays on the Theory and History of Security Production, ed. Hans-Hermann Hoppe, 239-274. Auburn, AL: Ludwig von Mises Institute.

Sechrest Larry. 2004. "Public Goods and Private Solutions in Maritime History". The Quarterly Journal of Austrian Economics 7, 2: 3-27.

Sechrest Larry. 2004. "Private Provision of Public Goods: Theoretical Issues and Some Examples from Maritime History”. ICFAI Journal of Public Finance II, 3: 45-73. 
Sechrest Larry. 2007. "Privately Funded and Built U.S. Warships in the Quasi-War of 1797-1801". The Independent Review 12, 1: 101-113.

Seligman Daniel. 1992. A Question of Intelligence, The IQ Debate in America. New York: Citadel, Carol Press.

Shaffer Butler. 2012. The Wizards of Ozymandias: Reflections on the Decline and Fall. Auburn, AL: The Mises Institute.

Shostak Frank. "Changes in the Money Supply Don't Cause Business Cycles". Mises Institute, 30.5.2017. Access 9.11.2021. https://mises.org/blog/changes-moneysupply-dont-cause-business-cycles.

Shugart II William F. 1987. "Don't Revise the Clayton Act, Scrap It!", Cato Journal 6: 925.

Sloterdijk Peter, "The Grasping Hand: The modern democratic state pillages its productive citizens". CITY JOURNAL, The Manhattan Institute, Winter 2010. Access 9.11.2021. http://www.city-journal.org/2010/20_1_snd-democratic-state.html.

Smith Jr. Fred L. "Why not Abolish Antitrust?". Competitive Enterprise Institute, 31.12.1982. Access 9.11.2021. http://cei.org/op-eds-and-articles/why-not-abolish-antitrust.

Sowell Thomas. 1975. Race and Economics. New York: Longman.

Sowell Thomas. 1981. Markets and Minorities. New York, N.Y.: Basic Books.

Sowell Thomas. 1982. "Weber and Bakke and the presuppositions of 'Affirmative Action"'. In: Discrimination, Affirmative Action and Equal Opportunity, eds. Walter E. Block, Michael Walker, 37-63. Vancouver: The Fraser Institute.

Sowell Thomas. 1983. The Economics and Politics of Race: An International Perspective. New York, William Morrow.

Sowell, Thomas. 1984. Civil Rights: Rhetoric or Reality. New York: William Morrow.

Sowell Thomas. 2000. Basic Economics: A Citizen's Guide to the Economy. New York, N.Y.: Basic Books.

Spooner Lysander. 1966 [1870]. No Treason: The Constitution of No Authority and A Letter to Thomas F. Bayard. Larkspur, Colorado: Rampart College.

Stringham Edward, ed. 2007. Anarchy and the Law: The Political Economy of Choice. Somerset, NJ: Transaction Publishers.

Tannehill Morris, Linda Tannehill. [1970] 1984. The Market for Liberty. New York: Laissez Faire Books.

Tinsley Patrick. 1998-1999. "With Liberty and Justice for All: A Case for Private Police". Journal of Libertarian Studies 14, 1: 95-100.

Tucker Jeffrey. 1998. “Controversy: Are Antitrust Laws Immoral?". Journal of Markets \& Morality 1, 1: 75-82.

Tucker Jeffrey. 1998. "Controversy: Are Antitrust Laws Immoral? A Response to Kenneth G. Elzinga”. Journal of Markets \& Morality 1, 1: 90-94. 
Vance Laurence. "The Right to Discriminate Is a Basic Property Right". Mises Institute, 24.3.2017. Access 9.11.2021. https://mises.org/blog/right-discriminatebasic-property-right.

Van Notten, M. 2005. The Law of the Somalis. Trenton, NJ: Red Sea Press.

Walker Deborah, Jerry W. Dauterive, Elyssa Schultz, Walter E. Block. 2004. "The Feminist Competition/Cooperation Dichotomy: A Critique". Journal of Business Ethics 55, 3: 241-252.

Wall Richard. "Who's Afraid of Noam Chomsky?". LewRockwell.com, 17.8.2004. Access 9.11.2021. https://www.lewrockwell.com/2004/08/richard-wall/whosafraid-of-noam-chomsky/.

Wenzel Robert. "Robert Ringer's Strawman Anarchist". LewRockwell.com, 2.2.2013. Access 9.11.2021. http://archive.lewrockwell.com/wenzel/wenzel211.html.

Whitehead Roy, Walter E. Block, Lu Hardin. 1999. "Gender Equity in Athletics: Should We Adopt a Non-Discriminatory Model?". The University of Toledo Law Review 30, 2: 223-249.

Whitehead Roy, Walter E. Block. 2002. "Sexual Harassment in the Workplace: A Property Rights Perspective". University of Utah Journal of Law and Family Studies 4: 226-263.

Whitehead Roy, Walter E. Block. 2004. “The Boy Scouts, Freedom of Association and the Right to Discriminate: A Legal, Philosophical and Economic Analysis". Oklahoma City Law Review 29, 3: 851-882.

Williams Walter E. 1982. The State Against Blacks. New York: McGraw-Hill.

Williams Walter E. 2011. Race and Economics: How Much Can Be Blamed on Discrimination? Stanford, CA: Hoover Institution Press.

Wood Paul. "First They Came for the Bakers". LewRockwell.com, 22.5.2015. Access 9.11.2021. https://www.lewrockwell.com/2015/05/no_author/first-they-camefor-the-bakers/.

Woods Thomas E. Jr. 2009. Meltdown: A Free-Market Look at Why the Stock Market Collapsed, the Economy Tanked, and Government Bailouts Will Make Things Worse. Washington, D.C.: Regnery Publishing.

Woods Thomas E. "Fashionable Libertarians Declare: HERE We Need Aggression!". LewRockwell.com, 7.6.2016. Access 9.11.2021. https://www.lewrockwell. com/2016/06/thomas-woods/forget-called-religious-liberty-laws/. 